\title{
The impact of Brexit on "bail-inable" liabilities under English law
}

\author{
Pier Mario Lupinu*
}

\begin{abstract}
Several years have passed since 29 March 2017, the date when the United Kingdom (UK) triggered Article 50 of the Treaty on European Union (TEU). This date has become well-known for paving the way to multiple legal and political issues, most of which depend on the agreement setting the conditions for the future relations between the European Union (EU) and the UK. In reference to the resolution of a credit institution established in the $E U$ in a state of imminent crisis, Brexit might negatively affect its shareholders and bondholders who were called upon to contribute by absorbing losses and recapitalising the bank through the bail-in instrument. In particular, when the bail-in converts or writes down liabilities previously established under English law. To date, the EU legal framework for the resolution of credit institutions envisages a provision for the direct recognition of liabilities governed under any of the EU Member States' law. This means that, due to Brexit, English law liabilities are no longer directly recognised at the EU level. However, the Bank Recovery and Resolution Directive (BRRD), one of the pillars of the EU legislation relating to resolution, leaves to each EU Member State the duty to require financial entities to include "resolutionproof" clauses in the contracts establishing such liabilities or, alternatively, to conclude a binding agreement with the relevant third country. This creates issues concerning both the recognition of English law liabilities established pre-BRRD and to post-BRRD liabilities not compliant with the contractual requirement. By analysing the EU and UK legal frameworks, this paper aims to address possible solutions to ease a future resolution procedure involving the use of the bail-in instrument towards English law liabilities. The purpose is to ease both the determination of the Minimum Requirement for own fund and Eligible Liabilities (MREL) and the resolution process for the relevant authority in charge of the resolution procedure, since an orderly bail-in of those problematic liabilities could improve the effectiveness of the instrument and the success of the whole resolution procedure.
\end{abstract}

\section{Introduction}


Since the 29 March 2017, ${ }^{1}$ when the UK triggered Article 50 of the TEU, ${ }^{2}$ EU and UK negotiators have been working towards reaching an agreement for the departure of the UK from the "bloc"3 (i.e., the EU). The banking sector failed to fully prepare ahead of the unprecedented withdrawal of a Member State from the EU. In August 2019, following the Council decision to extend the withdrawal period until the 31 October 2019, the European Central Bank (ECB) warned the euro area entities that "as a result of the delays observed, banks will not be able to fully implement their target operating models ${ }^{4}$ within the timelines agreed with their supervisors", 5 with the consequence that, euro area bank's negligence in preparing for Brexit "could have [had] a negative impact on banks' profitability". ${ }^{6}$ As a result, due to the recent expiration of the transition period, the new post-Brexit legal environment analysed in this paper might open the way for negative consequences on English law loan documentation and, therefore, on the resolution of banks.

As it will be discussed, a smooth resolution procedure for banks established in the European Union and having subsidiaries and/or branches in the $\mathrm{UK}^{7}$ is uncertain due to Brexit. ${ }^{8}$ The resolution of a bank represents a crisis management procedure handled by a resolution

\footnotetext{
* PhD Candidate in Banking and Finance Law at University of Luxembourg and Roma Tre University, supported by the Luxembourg National Research Fund (FNR) - 10965388.

${ }^{1}$ The decision to trigger Article 50 TEU was taken following the vote of the referendum on the 23 June 2016 in the United Kingdom, where the majority of the voters opted to leave the European Union. For the complete Brexit timeline, Nigel Walker, 'Research Briefing: Brexit timeline: events leading to the UK's exit from the European Union' [2020] House of Commons Library 7960

$<$ https://researchbriefings.parliament.uk/ResearchBriefing/Summary/CBP-7960\#fullreport> accessed 20 December 2020. See also European Commission, 'EU-UK Relations: From the UK referendum to a new Trade and Cooperation Agreement - Timeline' (2020) <https://ec.europa.eu/info/files/eu-uk-relations-uk-referendumnew-trade-and-cooperation-agreement-timeline_en> accessed 5 January 2021.

${ }^{2}$ Consolidated Version of the Treaty on European Union [2008] OJ C202/43.

${ }^{3}$ The term "bloc" means a trading bloc. Schott explains that a trading bloc is "an association of countries that reduces intra-regional barriers to trade in goods (and sometimes services [...] and capital as well)." See Jeffrey J. Schott, 'Trading Blocs and the World Trading System' [1991] 14 (1) The World Economy 1.

${ }^{4}$ Target operating models design how a bank has to be organised in order to deliver its strategy and goals in the most efficient way.

${ }^{5}$ On the topic, see European Central Bank, 'Brexit: stepping up preparations' (August 2019) European Central Bank Newsletter

$<$ https://www.bankingsupervision.europa.eu/press/publications/newsletter/2019/html/ssm.nl190814.en.html> accessed 20 February 2020.

${ }^{6}$ Ibid.

${ }^{7}$ Or for an EU subsidiary of a group headquartered in the UK.

${ }^{8}$ In 2018 the European Commission released a document addressed to stakeholders in order to warn them about risks potentially caused by Brexit in the field of banking and payment services. See European Commission, "Notice to Stakeholders "Withdrawal of the United Kingdom and EU Rules in the Field of Banking and Payment Services"” (2018) 3-4 < https://ec.europa.eu/info/sites/info/files/180208-notice-withdrawal-uk-bankingservices_en.pdf $>$ accessed 25 February 2020.
} 
authority (i.e. the Single Resolution Board - $\mathrm{SRB}^{9}$ - or the National Resolution Authority $\mathrm{NRA}^{10}$ - of each of the nineteen euro area Member States) ${ }^{11}$ in order to restructure a bank through the use of (one or a combination of) four resolution tools to safeguard public interests. ${ }^{12}$ This last-mentioned feature includes the continuity of the bank's critical functions and the preservation of financial stability at a minimal cost for taxpayers. Following the euro area sovereign debt crisis in 2012, ${ }^{13}$ EU lawmakers introduced this resolution framework through the adoption of the Bank Recovery and Resolution Directive (BRRD) ${ }^{14}$ to reduce negative spillover effects ${ }^{15}$ on the economic system and to avoid the cost of serious bailouts ${ }^{16}$ on taxpayers. Among the four resolution tools provided by the BRRD,${ }^{17}$ the bail-in instrument facilitates the absorption of losses and the recapitalisation of an entity through the write down ${ }^{18}$ and conversion ${ }^{19}$ of liabilities. ${ }^{20}$ In the framework of this instrument, Article 55 BRRD sets the

\footnotetext{
${ }^{9}$ See Pablo Iglesias-Rodríguez, 'The Concept of Systemic Importance in European Banking Union Law' in Mario P. Chiti and Vittorio Santoro (eds), The Palgrave Handbook of the European Banking Union Law (Palgrave Macmillan 2019) 192-199.

${ }^{10}$ Article 3(1)(3) of the Single Resolution Mechanism Regulation (SRMR) provides a definition of NRA. Moreover, in the Banking Union (BU), the relevant NRA of each of the participating Member States is responsible for banks other than those under the mandate of the SRB as stated in Article 7(2), (4)(b) and (5) SRMR. See Regulation (EU) 806/2014 of the European Parliament and of the Council of 15 July 2014 establishing uniform rules and a uniform procedure for the resolution of credit institutions and certain investment firms in the framework of a Single Resolution Mechanism and a Single Resolution Fund and amending Regulation (EU) 1093/2010 [2014] OJ L225/1.

${ }^{11}$ Please note that the BRRD has an EEA relevance, thus applying to all the EU Member States plus Iceland, Liechtenstein and Norway. However, the administrative authority responsible of leading the resolution procedure differs from the EEA to the BU, where the dualism SRB/NRAs - Significant Institutions (SIs)/Less Significant Institutions (LSIs) is absent and each non-participating (i.e., non-BU) Member State has its own (administrative) resolution authority which is not part of the Single Resolution Mechanism (SRM). On the topic, see Kern Alexander, 'European Banking Union: A Legal and Institutional Analysis of the Single Supervisory Mechanism and the Single Resolution Mechanism' [2015] European Law Review (2) 154-155.

${ }^{12}$ See Single Resolution Board, 'What is a Bank Resolution?' <https://srb.europa.eu/en/content/what-bankresolution> accessed 15 February 2020.

${ }^{13}$ The sovereign debt crisis in the euro area, according to Kräussl, Lehnert and Stefanova, was caused by "the subprime mortgage market in the U.S [which] ignited the 2008 banking crisis [turning] into a global recession. A series of financial sector bailouts in 2008 sparked a full-blown sovereign debt crisis in Europe." See Roman Kräussl, Thorsten Lehnert and Denitsa Stefanova, 'The European sovereign debt crisis: What have we learned?' (2017) Center for Financial Studies Working Paper Series 567

<https://www.econstor.eu/bitstream/10419/149623/1/87785405X.pdf> accessed 2 March 2020.

${ }^{14}$ Directive 2014/59/EU of the European Parliament and of the Council of 15 May 2014 establishing a framework for the recovery and resolution of credit institutions and investment firms and amending Council Directive 82/891/EEC, and Directives 2001/24/EC, 2002/47/EC, 2004/25/EC, 2005/56/EC, 2007/36/EC, 2011/35/EU, 2012/30/EU and 2013/36/EU, and Regulation (EU) 1093/2010 and (EU) 648/2012, of the European Parliament and of the Council [2014] OJ L173/190.

${ }^{15}$ Negative spillover events are domestic events that can spread consequences to other countries. Due to the highly interconnectedness of the financial sector, severe losses in the US can impact other economies as, for example, in Europe.

${ }^{16} \mathrm{~A}$ bailout is a procedure aimed at providing financial support to a distressed financial institution through public funding.

${ }^{17}$ The other three resolution tools are: the sale of business, the bridge bank and the asset separation.

${ }^{18}$ Reduction of the value of an asset to offset a loss or expense.

${ }^{19}$ This modification entails the conversion of debt (liability) into equity.

${ }^{20}$ In the banking sector, liabilities are obligations which are located at the right side of a bank's balance sheet.
} 
rules for the "contractual recognition of bail-in", ${ }^{21}$ as one of the key features ensuring the proper functioning of the bail-in tool and a frictionless MREL determination.

The advent of Brexit has created the potential disapplication of EU law in the UK due to the proposed repeal of relevant EU directives, including the BRRD. Consequently, the condition of contractual agreements establishing liabilities, as per English law, has suddenly become burdensome. Due to the lack of entrenchment of EU law, there is a risk that the automatic recognition of liabilities between the UK and the "remaining" EU Member States might no longer apply. In fact, the risk of no longer automatically recognising contractual liabilities could have unexpected negative consequences directly on the amount of liabilities which could be subject to conversion or write down when applying the bail-in tool. This issue will be analysed in the section concerning this specific resolution tool.

As a result, this could adversely impact the success of the whole resolution procedure by weakening the effectiveness of the application of the bail-in tool by reducing the amount of 'bail-inable' liabilities. Accordingly, this paper seeks to answer the question of how Brexit will impact the write down or conversion of liabilities and the related instruments governed under English law. This will be achieved by assessing the impact of Brexit on a future framework, in which contracts governed by English law, that an EU financial institution is a party to, will have to be compliant with Article $55,{ }^{22}$ due to the end of the transition period, and UK becoming a third country ${ }^{23}$ as of 1 February 2020, which resulted in the disapplication of EU law in the UK.

The current legal framework for the resolution of credit institutions, which applies to both the $\mathrm{BU}^{24}$ and the remaining non-participating EU Member States, ${ }^{25}$ requires banks to have

\footnotetext{
${ }^{21}$ Article 55, Bank Recovery and Resolution Directive (2014/59/EU).

${ }^{22}$ Starting from 1 January 2016, Article 55 BRRD requires entities under its remit to include contractual terms for the recognition of the bail-in tool for agreements governed by the law of third-country Member States. See also European Banking Authority, 'Consultation Paper "on the contractual recognition of write-down and conversion powers under Article 55(3) of the Bank Recovery and Resolution Directive (BRRD)"”

(EBA/CP/2014/33) $19<$ https://eba.europa.eu/eba-consults-on-contractual-recognition-of-bail-in> accessed on 26 February 2020.

${ }^{23}$ In the sense linked to this article, a "third country" is a State which is not part of the European Union. Such denomination is regularly used in the EU legislation.

${ }^{24}$ The BU was born as a response to the financial crisis with the aim of establishing deeper integration and lowering risks for the European economy. Despite not having reached yet full completion (lack of a BU wide Deposit Insurance Scheme), the first two pillars of the BU (supervision and resolution) are operational. On the future steps in order to complete the BU. Commission, 'Communication on completing the Banking Union' COM (2017) 592 final 1-20.

${ }^{25}$ Including EEA countries, see note 11 above.
} 
"resolution-proof" clauses in their contracts establishing liabilities. ${ }^{26}$ During the resolution phase, it is important to maintain operational continuity and to deliver critical functions to the economy where an entity operates. As a firm enters resolution, there is a concrete risk that some parties could opt to avoid risks through the termination of the contracts they have in place with the concerned entity. This is a clear example of a barrier to resolvability that can be removed by making contracts able to "survive" in case of resolution, and therefore, become "resolution-proof". ${ }^{27}$ Contracts which fall under the scope of this paper are those governed by the law of a third country, only if "the resolution authority of a Member State determines that the liabilities or instruments referred to in the first subparagraph [of Article 55 BRRD] can be subject to write down and conversion powers by the resolution authority of a Member State pursuant to the law of the third country or to a binding agreement concluded with that third country." ${ }^{28}$ Such determination from the resolution authority serves as a safeguard so that, in case of a resolution decision which applies the bail-in tool as the preferred resolution strategy, ${ }^{29}$ liabilities established with contracts under third-country law could be equally subject to the write down and conversion as those under EU law. ${ }^{30}$ This could help the enforcement of a cross-border resolution action. ${ }^{31}$

\section{The bail-in tool}

The bail-in tool, ${ }^{32}$ together with the sale of business tool, the bridge bank tool, and the asset separation tool, was initially established with the guiding principles for an effective bank resolution, namely the Financial Stability Board (FSB) Key Attributes of Effective Resolution

\footnotetext{
${ }^{26}$ For a broader explanation of the UK resolution regime, see Bank of England, 'The Bank of England's approach to resolution' (October 2017) <https://www.bankofengland.co.uk/paper/2017/the-bank-of-englandapproach-to-resolution> accessed 5 March 2020.

27 ibid.

${ }^{28}$ Article 55, Bank Recovery and Resolution Directive (2014/59/EU).

${ }^{29}$ The resolution strategies followed by the relevant resolution authority are those detailed in the resolution plan. See Article 10, Bank Recovery and Resolution Directive (2014/59/EU). It is important to specify that the solution in the plan is a preferred resolution strategy, meaning that all the authorities involved in the resolution procedure (e.g., for the BU, the European Commission, or the Council) can modify the strategy to be implemented. On the topic, see Single Resolution Board, 'The Single Resolution Mechanism - Introduction to Resolution Planning' $(2016)<\mathrm{https}$ ://srb.europa.eu/en/content/introduction-resolution-planning $>$ accessed 18 March 2020.

${ }^{30}$ These specific liabilities under EU law are governed by the BRRD.

${ }^{31}$ See Financial Stability Board, 'Principles for Cross-border Effectiveness of Resolution Actions' (November 2015) $6<\mathrm{https}: / / \mathrm{www}$.fsb.org/wp-content/uploads/Principles-for-Cross-border-Effectiveness-of-ResolutionActions.pdf $>$ accessed 18 March 2020.

${ }^{32}$ For an early analysis of the bail-in tool, and an explanation of "bail-inable" liability, see John Armour, 'Making Bank Resolution Credible' in Niamh Moloney, Eilís Ferran, and Jennifer Payne (eds), The Oxford Handbook of Financial Regulation (Oxford University Press 2015) 474-475.
} 
Regimes for Financial Institutions. ${ }^{33}$ This sets the foundation of the resolution framework. According to the FSB's Key Attributes Assessment Methodology for the Banking Sector, the bail-in tool is a restructuring mechanism enabling the absorption of losses and recapitalisation of a credit institution under a resolution procedure, including:

\section{"the effective capitalisation of a bridge institution through the cancellation, write-down or termination of equity, debt instruments and other senior or subordinated unsecured liabilities [...], and the conversion or exchange of all or part of such instruments or liabilities (or claims thereon) into or for equity in or other instruments issued by that bank, a successor (including a bridge institution) or a parent company of that bank. "34}

In other words, the bail-in tool aims to recover the losses faced by troubled credit institutions which are put under resolution.

In the interest of an efficient application of the bail-in tool, EU legislators decided to include the requirement for EU credit institutions in the BRRD, introducing a clause stating the recognition of the bail-in tool in their contracts with third-country parties. Such a requirement is line with the FBS's principles and, despite not ensuring absolute certainty about Court enforcement of such contracts, highlights the need for bail-in recognition clauses for strengthening the "cross-border enforceability of bail-in actions". 35

Further, this instrument allows the concerned party to the contract to be aware that the liabilities agreed upon, even if subject to the jurisdiction of a third country, could be subject to a write down or conversion. More specifically, the provision of Article 55 BRRD clearly sets that:

\footnotetext{
${ }^{33}$ See Financial Stability Board, 'Key Attributes of Effective Resolution Regimes for Financial Institutions' (October 2014) $9<$ https://www.fsb.org/work-of-the-fsb/policy-development/effective-resolution-regimes-andpolicies/key-attributes-of-effective-resolution-regimes-for-financial-institutions $>$ accessed 20 March 2020. For a critical view on bail-in and the risks that could arise from its application, including a parallel with bailouts, see Emilios Avgouleas and Charles Goodhart, 'Critical Reflections on Bank Bail-ins' [2015] 1 Journal of Financial Regulation 3-29<https://academic.oup.com/jfr/article/1/1/3/2357875> accessed 20 March 2020.

${ }^{34}$ See Financial Stability Board, 'Key Attributes Assessment Methodology for the Banking Sector' (October 2016) <https://www.fsb.org/2016/10/key-attributes-assessment-methodology-for-the-banking-sector/> accessed 4 April 2020.

${ }^{35}$ See Financial Stability Board, 'Principles on Loss-absorbing and Recapitalisation Capacity of G-SIBs in Resolution' (November 2015) 6-7 <https://www.fsb.org/wp-content/uploads/TLAC-Principles-and-Term-Sheetfor-publication-final.pdf $>$ accessed 4 April 2020.
} 
"[EU] Member States shall require institutions and entities [...] to include a contractual term by which the creditor or party to the agreement creating the liability recognises that liability may be subject to the write down and conversion powers and agrees to be bound by any reduction of the principal or outstanding amount due, conversion or cancellation that is effected by the exercise of those powers by a resolution authority, provided that such liability is: [...] (c) governed by the law of a third country. "36

Furthermore, Article 44 of the Commission Delegated Regulation 2016/1075 37 specifies the content that the contractual recognition clause has to include. ${ }^{38}$ Among other elements, it shall include a clear "acknowledgement and acceptance by the counterparty of an institution or entity [...] that the liability may be subject to the exercise of write-down and conversion powers by a resolution authority" 39 and "a description of the write-down and conversion powers of each resolution authority in accordance with the national law". 40

It is possible to determine that these provisions combine principles of information and transparency for the party who subscribes to the contract which establishes the liability. Likewise, they facilitate the application of the bail-in instrument by the relevant resolution authority. ${ }^{41}$ Additionally, Article $55 \mathrm{BRRD}^{42}$ foresees the possibility for the resolution

\footnotetext{
${ }^{36}$ Article 55, Bank Recovery and Resolution Directive (2014/59/EU).

${ }^{37}$ Commission Delegated Regulation (EU) 2016/1075 of 23 March 2016 supplementing Directive 2014/59/EU of the European Parliament and of the Council with regard to regulatory technical standards specifying the content of recovery plans, resolution plans and group resolution plans, the minimum criteria that the competent authority is to assess as regards recovery plans and group recovery plans, the conditions for group financial support, the requirements for independent valuers, the contractual recognition of write-down and conversion powers, the procedures and contents of notification requirements and of notice of suspension and the operational functioning of the resolution colleges [2016] OJ L184/1.

${ }^{38}$ It refers to Article 55(1) BRRD.

${ }^{39}$ Article 44, Commission Delegated Regulation 2016/1075.

${ }^{40}$ Ibid.

${ }^{41}$ Including the successive valuation procedure described in Article 36 BRRD. On the topic, see Willem Pieter de Groen, 'Valuation reports in the context of banking resolution: What are the challenges? Banking Union Scrutiny' [2018] Economic Governance Support Unit, European Parliament 8-9 $<$ https://www.europarl.europa.eu/RegData/etudes/IDAN/2018/624418/IPOL_IDA(2018)624418_EN.pdf> accessed 8 March 2020.

42 This Article became Article 55(3) with the adoption of the Directive 2019/879/EU of the European Parliament and of the Council of 20 May 2019 amending Directive 2014/59/EU as regards the loss-absorbing and recapitalisation capacity of credit institutions and investment firms and Directive 98/26/EC [2019] OJ L150/296 (BRRD2), but the text of the Article was left unchanged. The SRB detailed several elements which should constitute "a satisfactory legal opinion". See Single Resolution Board, 'Minimum Requirement for Own Funds and Eligible Liabilities (MREL). SRB Policy under the Banking Package' (2020) 32

$<\mathrm{https}$ ://srb.europa.eu/sites/srbsite/files/srb_mrel_policy_2020.pdf> accessed 12 March 2020.
} 
authority to request legal opinions to ensure the recognition of the bail-in clause in the thirdcountry jurisdiction.

The recent amendments to the whole resolution framework were introduced in the Banking Package, which modified certain core provisions concerning bail-inable liabilities. Thus, the BRRD has been amended by Directive 2019/879/EU, known as BRRD2. While the latter left unaltered the previously mentioned requirements of Article 44, it substantially changed Articles 45 and 55 BRRD. Article 45 BRRD $^{43}$ in its former design allowed the concerned resolution authority to disregard certain liabilities in case that it would not be possible to demonstrate the effectiveness of the bail-in. This was modified with the adoption of the BRRD2, in particular by Article 55(2), ${ }^{44}$ which introduced more restrictions by ruling out the discretion of the resolution authority, and determining the exclusion of the liability under two conditions: the absence of a cross-border framework agreement for its recognition, or the lack of a recognition clause. ${ }^{45}$ However, it is necessary to stress that the above principles do not apply to liabilities established before the transposition of the original BRRD text on 31 December 2014, ${ }^{46}$ which includes the liabilities governed under English law established until the above deadline.

Further, there is a possibility for credit institutions under the remit of the BRRD to avoid the incorporation of the bail-in clause for reasons of "impracticability". In Recital 26 of BRRD2, the European legislator set conditions for determining such 'impracticability':

"... in cases where it is illegal under the law of the third country for an institution or entity to include such clauses in agreements or instruments creating liabilities that are governed by the laws of that third country, where an institution or entity has no power at the individual level to amend the contractual terms as they are imposed by international protocols or are based on internationally agreed standard terms, or where the liability which would be subject to the contractual recognition requirement is contingent on a

\footnotetext{
${ }^{43}$ Article 45, Bank Recovery and Resolution Directive (2014/59/EU).

${ }^{44}$ Article 55(2), Directive 2019/879/EUOJ L 150, 7.6.2019, p. 337. See also Single Resolution Board (2020b), p. 31 .

${ }^{45}$ Such a clause should follow Article 55(1) BRRD2.

${ }^{46}$ It must be signaled that, by the date of the transposition deadline, only two EU Member States were compliant. Cf. Commission, 'Communication on the application and review of Directive 2014/59/EU (Bank Recovery and Resolution Directive) and Regulation 806/2014 (Single Resolution Mechanism Regulation)’ COM (2019) 213 final 2.
} 
breach of contract or arises from guarantees, counter-guarantees or other instruments used in the context of trade finance operations. ",47

Nevertheless, the same Recital highlights that if one of the Parties (to the agreement which establishes the third-country law liability) refuses to be constrained "by a contractual bail-in recognition clause (such choice cannot be itself) be considered as a cause of impracticability", ${ }^{48}$ a feature which may be related to the situation analysed in this paper. In this framework, EBA is expected to "identify cases of impracticability." 49 By means of a public consultation, in July 2020 the EBA started its work on the "on draft Regulatory Technical Standards (RTS) and draft Implementing Technical Standards (ITS) on the impracticability of contractual recognition of write-down and conversion powers", ${ }^{50}$ which were submitted to the Commission and adopted on 23 December $2020 .{ }^{51}$

\section{The MREL requirement}

The element which demonstrates the importance of the protection of "bail-inable" liabilities, is the determination of the Minimum Requirement for own funds and Eligible Liabilities (MREL). The MREL is a condition which requires banks to ensure that they, at all times, have sufficient resources written down or converted into equity if they incur losses. It secures a minimum amount of a specific type of liabilities, ${ }^{52}$ which can be used to "ensure that banks at all times have enough capital and eligible liabilities to facilitate" 53 the absorption of the losses and recapitalisation (in case of application of the bail-in tool), thus favouring the

\footnotetext{
${ }^{47}$ Recital 26, Directive 2019/879/EU.

48 Ibid.

${ }^{49}$ Ibid. The EBA duty is based on Articles 10-14 of Regulation 1093/2010.

${ }^{50}$ European Banking Authority, 'EBA consults on technical standards on impracticability of contractual recognition of bail-in' (2020) < https://www.eba.europa.eu/eba-consults-technical-standards-impracticabilitycontractual-recognition-bail $>$ accessed 8 January 2020. Such RTS and ITS are based on, respectively, Articles 55(6) and (8) Directive 2014/59/EU (BRRD).

${ }^{51}$ See European Banking Authority, 'EBA publishes final draft technical standards on impracticability of contractual recognition under the BRRD framework' $(2020)<$ https://www.eba.europa.eu/eba-publishes-finaldraft-technical-standards-impracticability-contractual-recognition-under-brrd $>$ accessed 8 January 2020.

${ }^{52}$ Liabilities which count for the MREL are calculated based on the requirements of Articles 92 and 500 Regulation (EU) 575/2013 of the European Parliament and of the Council of 26 June 2013 on prudential requirements for credit institutions and investment firms and amending Regulation (EU) 648/2012 [2013] OJ L176/1 (CRR) and Articles 104 and 128 Directive 2013/36/EU of the European Parliament and of the Council of 26 June 2013 on access to the activity of credit institutions and the prudential supervision of credit institutions and investment firms, amending Directive 2002/87/EC and repealing Directives 2006/48/EC and 2006/49/EC [2013] OJ L176/338 (CRD). For the methodology developed by the SRB, which is based on the criteria outlined in the BRRD, see Single Resolution Board, 'MREL: Approach taken in 2016 and next steps' (2016) 14-16 <https://srb.europa.eu/sites/srbsite/files/srb_mrel_approach_2016_post_final.pdf $>$ accessed 30 April 2020.

${ }^{53}$ Ibid 8.
} 
continuation of its critical functions. ${ }^{54}$ According to Article 12(1) and (2) of the Single Resolution Mechanism Regulation (SRMR), the MREL is determined by Single Resolution Board (SRB) $)^{55}$ and National Resolution Authorities (NRAs) ${ }^{56}$ towards banks under the scope of the Regulation. ${ }^{57}$ Resolution authorities in the European Union are in charge of the MREL determination. ${ }^{58}$ Hence, they have to assess whether the liabilities to be count as MREL are suitable and qualify for such amount.

In relation to the main issue of this paper, a number of liabilities established with contracts governed by English law, which were already deemed eligible for the MREL requirement, would require the concerned EU resolution authorities to redetermine such amount in case the UK decided not to apply the BRRD (or not to align to its standards). This paper argues that, even in the event of the repeal of the BRRD by the UK, it might (most probably) continue to follow and apply the Total Loss-Absorbing Capacity (TLAC) standards for its Global Systemically Important Banks (G-SIBs), which have the same purpose of the MREL. Although TLAC and MREL are quite similar in scope, TLAC applies only to G-SIBs, while MREL applies to all European banks. This means that all UK banks were included in the scope of the MREL, which is why the UK might decide to reduce requirements to only its GSIBs, following the US approach. ${ }^{59}$ In any case, small and medium sized credit institutions (i.e., LSIs), due to their modest and domestic activities, are less likely to hold liabilities established under English law. Instead, G-SIBs and other big entities, by virtue of their global

\footnotetext{
${ }^{54}$ Critical functions are those "activities performed by a bank for third parties, where failure would lead to disruption of services critical to the functioning of the real economy and for preserving financial stability" as lending to Small and medium-sized enterprises (SMEs), see Jens-Hinrich Binder, 'Resolution, Concepts, Requirements and Tools', in Jens-Hinrich Binder and Dalvinder Singh (eds), Bank Resolution: The European Regime (Oxford University Press 2016) 13-14, Financial Stability Board, 'Key Attributes Assessment Methodology for the Banking Sector' (October 2016) <https://www.fsb.org/2016/10/key-attributes-assessmentmethodology-for-the-banking-sector/> accessed 20 April 2020, and specifically for the identification of critical functions, Financial Stability Board, 'Guidance on Identification of Critical Functions and Critical Shared Services' (July 2013) < https://www.fsb.org/2013/07/r_130716a/> accessed 20 April 2020. For the SRB's approach to Critical Functions, see Single Resolution Board, 'Critical Functions: SRB Approach' (2017) $<$ https://srb.europa.eu/sites/srbsite/files/critical_functions_final.pdf $>$ accessed 20 April 2020.

${ }^{55}$ With the consultation of the ECB and other competent authorities. See Article 12, Single Resolution Mechanism Regulation (806/2014).

${ }^{56}$ Ibid.

${ }^{57}$ The determination of the MREL for banks established within the BU is a duty of (respectively) the SRB and NRA(s). However, it should be clear that MREL requirements arising from the BRRD as from Article 45 BRRD apply to all banks established in the European Union.

${ }_{58}$ As stated in Article 12(1), Single Resolution Mechanism Regulation (806/2014).

${ }^{59}$ The US focuses on setting TLAC standards for its largest institutions, not having a similar requirement for smaller entities. See Financial Stability Board, 'Principles on Loss-absorbing and Recapitalisation Capacity of G-SIBs in Resolution' (November 2015) 6-7 <https://www.fsb.org/wp-content/uploads/TLAC-Principles-andTerm-Sheet-for-publication-final.pdf $>$ accessed 3 May 2020.
} 
operations, are presumably more at risk concerning the determination of their MREL or TLAC requirements and the effective application of the bail-in tool in case of their resolution.

In order to prevent such an adverse scenario, the issue concerning "bail-inable" liabilities was already flagged in late 2017 in an Opinion by the EBA. ${ }^{60}$ It specified that, in the post-Brexit scenario, "English law instruments should be treated no differently from any other non-EU [i.e., third-country] instruments, in the absence of an agreement to the contrary." ${ }^{61}$ The Opinion of the EBA was not just serving as a warning about the treatment of post-Brexit English law liabilities. It advised resolution authorities of the EU to instruct credit institutions under their remit to include the Article 55 BRRD clause to safeguard the eligibility of their newly "issue[d] MREL-eligible instruments under English law"62 or otherwise opt to issue the same instruments under the law of any of the other EU-27 Member States. The EBA also suggests renegotiating contracts that lack a "resolution-proof" clause. However, the renegotiation of such contracts would be possibly taken as the last option by EU credit institutions as it is an expensive operation which increases the risk of concluding a new more costly contract, due to the new safeguards that will have to be included. ${ }^{63}$ Apart from MREL concerns, the EBA suggests that EU resolution authorities should still ensure that those English law liabilities would be subject to a bail-in procedure. ${ }^{64}$

This paper also reflects on the consequences of Brexit for the MREL of all the European Union's credit institutions, included those of the BU. ${ }^{65}$ Therefore, it is important to mention an additional duty of resolution authorities of the participating MS of the BU arising from Article 12(17) SRMR. In the circumstance covered by this Article, which is the situation of a thirdcountry law liability, the SRB can instruct the relevant NRA(s) to "require the institution to

\footnotetext{
${ }^{60}$ In 2018, the ECB set supervisory expectations based on this EBA Opinion. See European Central Bank, 'Supervisory expectations on booking models' (August 2018) 3

$<$ https://www.bankingsupervision.europa.eu/banking/relocating/shared/pdf/ssm.supervisoryexpectationsbooking models_201808.en.pdf $>$ accessed 10 May 2020.

${ }^{61}$ See European Banking Authority, 'Opinion "on issues related to the departure of the United Kingdom from the European Union"' EBA/Op/2017/12 18

$<$ https:/eba.europa.eu/sites/default/documents/files/documents/10180/1756362/81e612c6-dcab-4c4b-87e932784cb44de1/EBA\%20Opinion\%20on\%20Brexit\%20Issues\%20\%28EBA-Op-2017-12\%29.pdf?retry=1> accessed on 11 May 2020.

${ }^{62}$ Ibid.

${ }^{63}$ The Prudential Regulation Authority (PRA) advised that the modification would require "contract renegotiation costs." See Bank of England, 'The contractual recognition of bail-in: amendments to Prudential Regulation Authority rules' Consultation Paper 8/16 $10<\mathrm{https}$ ://www.bankofengland.co.uk//media/boe/files/prudential-regulation/consultation-paper/2016/cp816> accessed 15 May 2020.

${ }^{64}$ European Banking Authority, 'Opinion "on issues related to the departure of the United Kingdom from the European Union”” EBA/Op/2017/12 19.

${ }^{65}$ Always considering that the MREL applies also to institutions based in EEA Member States.
} 
demonstrate that any decision of the [SRB] to write down or convert that liability would be effected under the law of that jurisdiction." 66 The SRMR suggests (in quite broad terms) that the NRA(s) should verify the compliance of the concerned liabilities with bail-in powers through the contractual terms of the liability or "international agreements on the recognition of resolution proceedings." 67 This last requirement (examined in the following section) would be preferable for the current post-Brexit scenario as the Parties [i.e., EU and UK] have to handle the issue of the recognition of "bail-inable" liabilities beyond the recently concluded transition period.

In the interest of safeguarding resolution powers in the BU, the SRB issued a position paper drawing the attention to key areas that could be affected by Brexit, including MREL. The SRB reiterated the need to include bail-in recognition clauses in contracts issuing MREL and "governed by the laws of the UK or third countries". ${ }^{68}$ At the same time, with the aim of achieving legal certainty, the SRB suggested that banks issue MREL instruments "under the governing law of one of the EU27 Member States". ${ }^{69}$ The SRB acknowledged that possible MREL shortfalls could arise because of Brexit and, as it was already flagged, some MREL issuances under English law could become ineligible. As a result, these instruments could "rank pari passu with MREL eligible liabilities negatively impacting the no creditor worse-off risk". ${ }^{70}$ In other words, having contracts in force that are not "resolution-proof" represents a risk of complicating a future resolution procedure. If the contractual provisions would not be adopted to all the third-country law bail-inable liabilities, there could be the risk that the creditors with similar claims will not be treated fairly, breaking the no creditor worse off (NCWO) principle. ${ }^{71}$

This SRB approach was confirmed in its latest policy concerning MREL issuances under the new Banking Package. ${ }^{72}$ The SRB dedicated an entire section to liabilities issued under third-country law, which proves the growing interest and concern for this matter. The

\footnotetext{
${ }^{66}$ Article 12(17), Single Resolution Mechanism Regulation (806/2014).

67 Ibid.

${ }^{68}$ See Single Resolution Board, 'Single Resolution Board expectations to ensure resolvability of banks in the context of Brexit. SRB Position Paper' (November 2018) 3

$<$ https://srb.europa.eu/sites/srbsite/files/brexit_position_paper.pdf $>$ accessed 2 June 2020.

${ }^{69}$ Ibid.

${ }^{70}$ Ibid.

${ }^{71}$ See Sven Schelo, Bank Recovery and Resolution (Kluwer Law International 2015) 82-84.

${ }^{72}$ See Single Resolution Board, 'Minimum Requirement for Own Funds and Eligible Liabilities (MREL). SRB Policy under the Banking Package' (2020) <https://srb.europa.eu/sites/srbsite/files/srb_mrel_policy_2020.pdf> accessed 20 June 2020 and the previous section of this paper concerning the bail-in tool.
} 
relevance of the topic is directly associated with the changes introduced by the BRRD2 in favour of Article $55 .{ }^{73}$ In this document, the SRB confirmed the willingness to exclude certain liabilities from the MREL amount whether they would jeopardise the "effective exercise of the write-down and conversion powers", ${ }^{74}$ notwithstanding the governing law of these same instruments. This interpretation is in line with Recital 26 of the BRRD2 which states that "in order to ensure that the resolvability of institutions and entities is not affected, liabilities for which the relevant contractual provisions are not included should not be eligible for the MREL."75 Moreover, it stated that the responsibility to ensure the eligibility of such instruments lies within the banks, ${ }^{76}$ an interpretation already affirmed in $2018 .^{77}$

Lastly, for the sake of clarity and to guide banks towards resolvability, the SRB stressed the need for credit institutions to include "contractual bail-in recognition clauses for eligible liabilities governed by the law of third countries"78 in its Expectations for Banks. In this way, holders of this type of liabilities will "explicitly recognise that [their] liability may be subject to the write-down and conversion powers and other relevant powers of EU resolution authorities". 79

\section{Bail-inable liabilities in the English law}

After having discussed the EU legal background, this section examines the protection of bail-inable liabilities established under English law. In the UK, the Financial Services (Banking Reform) Act 2013, through the Bail-In Recognition Clause (BIRC), sets out the implementation of powers arising from the BRRD through the Bail-in stabilisation option. ${ }^{80}$ This includes, among others, the competence of the Bank of England to write down and convert

\footnotetext{
${ }^{73}$ Article 55, Directive 2019/879/EU.

${ }^{74}$ See Single Resolution Board, 'Minimum Requirement for Own Funds and Eligible Liabilities (MREL). SRB Policy under the Banking Package' (2020) 33

$<$ https://srb.europa.eu/sites/srbsite/files/srb_mrel_policy_2020.pdf $>$ accessed 20 June 2020 and the previous section of this paper concerning the bail-in tool.

${ }^{75}$ Recital 26, Directive 2019/879/EU.

${ }^{76}$ Single Resolution Board, 'Minimum Requirement for Own Funds and Eligible Liabilities (MREL). SRB Policy under the Banking Package' (2020) 33

$<$ https://srb.europa.eu/sites/srbsite/files/srb_mrel_policy_2020.pdf $>$ accessed 20 June 2020 and the previous section of this paper concerning the bail-in tool.

${ }^{77}$ Cf. Single Resolution Board, 'Single Resolution Board expectations to ensure resolvability of banks in the context of Brexit. SRB Position Paper' (November 2018)

$<$ https://srb.europa.eu/sites/srbsite/files/brexit_position_paper.pdf $>$ accessed 25 June 2020.

${ }^{78}$ See Single Resolution Board, 'Expectations for Banks' (March 2020) 20-21

$<$ https://srb.europa.eu/sites/srbsite/files/efb_main_doc_final_web_0.pdf $>$ accessed 26 June 2020.

79 Ibid.

${ }^{80}$ Financial Services (Banking Reform) Act 2013, Chapter 33, Part 3(17).
} 
liabilities, which represents the application of the bail-in instrument. This is the same power mandated by the SRMR to resolution authorities in the BU. ${ }^{81}$ Article 55 BRRD is also incorporated in the Policy Statement (PS) 17/16 of the PRA Rulebook, ${ }^{82}$ which has the function of providing feedback to the Consultation Paper $8 / 16^{83}$ on the amendments to PRA rules concerning the contractual recognition of bail-in. ${ }^{84}$ PS 17/16 states that "Article 55 requires firms to include in certain non-EU law contracts governing liabilities a term by which the relevant creditor or party to the contract recognises that the liability may be bailed in by the Bank of England as resolution authority" ${ }^{85}$ For this reason, Policy Statement 17/16 "is relevant to BRRD undertakings [i.e., firms under the remit of the directive] to which the Contractual Recognition Part of the PRA Rulebook applies." ${ }^{~}{ }^{6}$ Moreover, the stability of liabilities created within the EU is compounded by the fact that "for EU law governed contracts, the BRRD will automatically apply and no explicit clause is required", 87 exposing vulnerabilities for future contracts under post-Brexit English law. In the case that EU law would no longer be applicable in the UK, as no clause was previously required in contracts establishing liabilities governed by English law (or having a Party to the contract subject to the UK legislation), in the absence of an explicit recognition explained below, the write down or conversion of such liabilities would become highly problematic. In fact, the Article 55 requirement presupposes that "the creditor or party [from a third country] creating the liability [on or after $1^{\text {st }}$ January 2016] is expected to recognise that [it] may be written down or converted" 88 in case of a resolution

\footnotetext{
${ }^{81}$ Article 21(1) Single Resolution Mechanism Regulation (806/2014) gives the powers to write down or convert liabilities to the SRB, which (according to Article 22 SRMR) instructs the NRAs to exercise those powers.

${ }^{82}$ For the full statement, see Bank of England, 'The contractual recognition of bail-in: amendments to Prudential Regulation Authority rules' Policy Statement 17/16<https://www.bankofengland.co.uk/prudentialregulation/publication/2016/the-contractual-recognition-of-bail-in-amendments-to-pra-rules $>$ accessed 5 July 2020.

${ }^{83}$ Bank of England, 'The contractual recognition of bail-in: amendments to Prudential Regulation Authority rules' Consultation Paper 8/16<https://www.bankofengland.co.uk//media/boe/files/prudential-regulation/consultation-paper/2016/cp816> accessed 6 July 2020.

${ }^{84}$ Bank of England, 'The contractual recognition of bail-in: amendments to Prudential Regulation Authority rules' Policy Statement 17/16<https://www.bankofengland.co.uk/prudential-regulation/publication/2016/thecontractual-recognition-of-bail-in-amendments-to-pra-rules> accessed 7 July 2020.

${ }^{85}$ Ibid 5. According to the Banking Act 2009, Chapter 1, the Bank of England is the designated authority for exercising resolution powers, which are called "stabilisation powers".

${ }^{86}$ Ibid.

${ }^{87}$ See Laura Hingley and Philip Prowse, 'Trade Finance: the Challenges of the Requirement for Contractual Recognition of Bail-In' [2016] Oxford Business Law Blog <https://www.law.ox.ac.uk/business-lawblog/blog/2016/10/trade-finance-challenges-requirement-contractual-recognition-bail > accessed 15 July 2020. ${ }^{88}$ See Amelie Labbé, 'Bail-in recognition clauses decrypted' [2016] International Financial Law Review 1.
} 
procedure. This condition protects third-country contractual parties and informs them of their possible exposure to the losses of a failing financial entity. ${ }^{89}$

The choice of the European legislators to avoid direct recognition of third-country law liabilities could be linked to the need to leave a certain degree of discretion to the national authorities in the application of the bail-in tool against liabilities established with contracts under the law of a third country. Accordingly, the decision of including a contractual clause for the recognition of the liabilities under third-country law, as valid for write down or conversion in case of the application of the bail-in tool, has been put on the shoulders of the EU Member State resolution authorities. Indeed, under Article 45(5) BRRD, any resolution authority of the BU may request an entity to prove that any decision to write down or convert liabilities coming from one of the resolution authorities will be recognised under the law of the third country. ${ }^{90}$ In such a case, the preferable solution would be the conclusion of an ad-hoc binding agreement between the EU resolution authority of a specific Member State and the third-country party to the contract (i.e., the UK in the case of Brexit) on the recognition of the concerned liabilities. The inclusion of BIRCs in contracts governed by third-country law, where EU credit institutions are one of the parties, might encourage them not to comply immediately with the Article 55 requirement. In fact, credit institutions could be reluctant to proceed with the renegotiation of such contracts to protect themselves from additional costs. This can be explained with the fact that after the gradual adoption of the contractual recognition of the bail-in requirement by the PRA, ${ }^{91}$ the same authority introduced the possibility of a waiver. By means of this waiver, the PRA allowed concerned institutions to not apply the requirement for phase 2 liabilities as of 1 January 2016, delaying it to 30 June 2016. This

\footnotetext{
${ }^{89}$ Recital 26 of the Directive 2019/879/EU (BRRD2) states that "contractual recognition arrangements should help to reinforce the awareness of creditors under contractual arrangements that are not governed by the law of a Member State of possible resolution action with regard to institutions or entities that are governed by Union law."

90 See Article 45(5), Bank Recovery and Resolution Directive (2014/59/EU). However, as it was explained in the last paragraph of the above section on the bail-in tool, such requirement was modified with the adoption of the BRRD2, including the new Article 55(3).

91 The PRA calls this graduality as a "phased approach". It differentiates between phase 1 and phase 2 liabilities. Phase 1 liabilities include unsecured debt instruments, additional tier 1 (AT1), and tier 2 instruments. On the other hand, phase 2 liabilities consist of "unsecured liabilities which are not debt instruments". See Bank of England, 'The contractual recognition of bail-in: amendments to Prudential Regulation Authority rules' Consultation Paper 8/16 $6<$ https://www.bankofengland.co.uk/-/media/boe/files/prudentialregulation/consultation-paper/2016/cp816> accessed 18 July 2020.
} 
waiver could have been granted for reasons related to the "impracticability" 92 of its application, which proves the previously mentioned renegotiation issues.

Attention must be drawn to the extension to the Temporary Transitional Power (TTP), ${ }^{93}$ established with the Financial Services and Markets Act 2000 (Amendment) (EU Exit) Regulations 2019' Statutory Instrument (SI), which allows the BoE and the PRA to delay certain regulatory changes brought up by Brexit and to cope with the end of the transition period. The BoE and the PRA stated that three fundamental exceptions will not benefit from delays granted via the TTP. Of which, two out of the three concern bail-in clauses. On one side, the "transitional relief" 94 will not be conceded to liabilities that should count as MREL, except phase two liabilities. On the other side, the same will apply to EEA-law contracts.

\section{Recent Brexit Developments}

The definitive departure of the UK from the EU started late 2019 with a statement by Prime Minister Boris Johnson, ${ }^{95}$ to "get Brexit done" 96 by 31 January 2020. A few weeks earlier, on 28 October 2019, the Council announced a new "Brexit date" with a draft Decision, ${ }^{97}$ and voted the related official Decision ${ }^{98}$ on 30 October 2019. On the same day, the UK voted the "Exit Day" amendment. ${ }^{99}$ On 19 December 2019, the UK Government published the European Union (Withdrawal Agreement) Bill ${ }^{100}$ which, after receiving Royal Assent by the Queen, ${ }^{101}$ officially became an Act of the Parliament, the 'European Union (Withdrawal

\footnotetext{
92 Ibid 6-7. For PRA conditions to determine impracticability, see Bank of England, 'The contractual recognition of bail-in: impracticability' Supervisory Statement 7/16

$<$ https://www.bankofengland.co.uk/prudential-regulation/publication/2016/the-contractual-recognition-of-bailin-impracticability-ss $>$ accessed 30 July 2020.

${ }^{93}$ See Bank of England, 'Temporary transitional power' (2020) $<$ https://www.bankofengland.co.uk/euwithdrawal/temporary-transitional-power> accessed 9 January 2020.

94 Ibid.

${ }^{95}$ Following the UK's General Elections of the 12 December 2019, introduced with the Early Parliamentary General Election Act 2019, Chapter 29.

${ }^{96}$ See Boris Johnson, 'PM statement in Downing Street' (13 December 2019)

$<$ https://www.gov.uk/government/speeches/pm-statement-in-downing-street-13-december-2019> accessed 3 August 2020.

${ }^{97}$ Council Decision (EU) [...]/2019 taken in agreement with the United Kingdom of [...] October 2019 "extending the period under Article 50(3) TEU" (EUCO XT 20024/1/19 REV 1/1). Also, for the communication acknowledging the receipt of the draft Council Decision and PM Boris Johnson's comments, see Boris Johnson, 'Prime Minister's letter to President Donald Tusk' (19 October 2019)

$<$ https://www.gov.uk/government/publications/prime-ministers-letter-to-president-donald-tusk-19-october2019> accessed 3 August 2020.

${ }^{98}$ Council Decision (EU) 2019/1810 taken in agreement with the United Kingdom of 29 October 2019 extending the period under Article 50(3) TEU [2019] OJ L278I/1.

${ }^{99}$ See European Union (Withdrawal) Act 2018 (Exit Day) (Amendment) (No. 3) 2019, Regulation 2 No 1423.

${ }^{100}$ See European Union (Withdrawal Agreement) Bill 2019.

${ }^{101}$ Royal Assent, Volume 670.
} 
Agreement) Act 2020' ${ }^{102}$ After approval by the European Parliament ${ }^{103}$ and the subsequent final vote by the Council, ${ }^{104}$ as of the 31 January 2020 the Agreement on the withdrawal of the UK from the EU is in force. ${ }^{105}$ Upon official withdrawal from the EU, starting from 1 February 2020 the UK has entered a transition period. This means that (until its expiration) even if Article 50(3) TEU states that "the Treaties shall cease to apply to the State in question [i.e., the UK] from the date of entry into force of the withdrawal agreement", ${ }^{106}$ according to Article 127 of the Withdrawal Agreement, ${ }^{107}$ the same Treaties and, generally, EU law still apply as the day before. ${ }^{108}$ This includes all the provisions related to Article 55 BRRD.

The transition period, which lasted until the end of 2020, represented the most important phase because the EU and the UK had - in principle - to conclude by this date any agreement to set their future relationship. The Parties could have decided to extend the transition period only once, for a maximum of two years, and with a decision by the EU-UK Joint Committee to extend that period being taken before 1 July 2020. While the COVID-19 pandemic slowed down the negotiations, contrary to expectations, the extension was not requested. Following several weeks of uncertainty, and 10 months of negotiations, ${ }^{109}$ the

\footnotetext{
${ }^{102}$ European Union (Withdrawal Agreement) Act 2020, Chapter 1.

${ }^{103}$ See European Parliament Resolution on the state of play of the UK's withdrawal from the European Union (P9_TA(2019)0016/1).

104 See the Agreement on the withdrawal of the United Kingdom of Great Britain and Northern Ireland from the European Union and the European Atomic Energy Community [2020] OJ L29/1 and the Council Decision (EU) 2020/135 on the conclusion of the Agreement on the withdrawal of the United Kingdom of Great Britain and Northern Ireland from the European Union and the European Atomic Energy Community [2020] OJ L29/1. 105 Ibid.

${ }^{106}$ Consolidated Version of the Treaty on European Union [2008] OJ C202/43. On the topic, see also European Parliament, 'Article 50 TEU: Withdrawal of a Member State from the EU', European Parliamentary Research Service PE (2016) 577.971 1-8 $<$ https://www.europarl.europa.eu/RegData/etudes/BRIE/2016/577971/EPRS_BRI(2016)577971_EN.pdf> accessed 8 August 2020.

${ }^{107}$ Agreement on the withdrawal of the United Kingdom of Great Britain and Northern Ireland from the European Union and the European Atomic Energy Community [2020] OJ L29/1.

${ }^{108}$ See Bank of England, 'Prudential Regulation Authority Rulebook Online' (2020)

$<$ http://www.prarulebook.co.uk/> accessed 8 August 2020.

${ }^{109}$ See Stefano Fella and others, 'Briefing Paper: The UK-EU Trade and Cooperation Agreement: summary and implementation' [2020] House of Commons Library $09106<$ https://commonslibrary.parliament.uk/researchbriefings/cbp-9106-2/> accessed 2 January 2021.
} 
Parties announced the conclusion of the Trade and Cooperation Agreement (TCA) ${ }^{110}$ to be ratified $^{111}$ on 24 December $2020,{ }^{112}$ definitively averting a no-deal scenario.

Due to the lengthy timeline of the full ratification process, the Commission made a proposal "to apply the [TCA] on a provisional basis [...] until 28 February 2021."113 The procedure follows with the proposal of "Council decisions on the signature and provisional application" 114 by the Commission and, after the Council's unanimous approval, the TCA can be signed and receives consent by the European Parliament.

Notwithstanding the settlement of some of the crucial points that were dividing the two Parties until the very last moment, noticeable uncertainty has been left in various fields. Concerning financial services, which is the sole focus of this paper, the Agreement contains less provisions in this area compared to the 2017 Comprehensive Economic and Trade Agreement (CETA) with Canada. ${ }^{115}$ The TCA does not contain any equivalence decisions in the field of financial services. Undeniably, the Parties have had more politically sensitive negotiations to undertake (i.e., level playing field, governance and fisheries) than to focus on the recognition of third-country law contractual liabilities. However, the recommendation issued by the European Commission, ${ }^{116}$ asking the Council for authorisation to formally open the negotiations with the UK and, simultaneously, to be nominated as a negotiator on behalf of the EU, is important for the current analysis. Section IV of the document gives an idea of the strategy that the EU and the UK wanted to pursue. Financial stability falls within the scope of this study as making UK liabilities "bail-inable" post-Brexit, would ensure a smooth application of the bail-in tool and an easier resolution procedure. Apart from the preservation

\footnotetext{
${ }^{110}$ See Trade and Cooperation Agreement between the European Union and the European Atomic Energy Community, of the One Part, and the United Kingdom of Great Britain and Northern Ireland, of the Other Part [2020] OJ L444/14.

${ }^{111}$ Please note that full ratification envisages, from the UK side, ratification by both Houses of Commons and Lords followed by a Royal Assent and, from the EU side, ratification by the European Parliament, Council of the European Union and each parliament of its 27 Member States.

${ }^{112}$ Some referred to it as the "Christmas Eve Deal" because of the date of its conclusion.

${ }^{113}$ See European Commission, 'EU-UK Trade and Cooperation Agreement: protecting European interests, ensuring fair competition, and continued cooperation in areas of mutual interest' (2020)

$<$ https://ec.europa.eu/commission/presscorner/detail/en/ip 20_2531> accessed 5 January 2021.

${ }^{114}$ Ibid.

${ }^{115} \mathrm{Cf}$. Comprehensive Economic and Trade Agreement (CETA) between Canada, of the one part, and the European Union and its Member States, of the other part [2017] OJ L11/23.

${ }^{116}$ See Commission, 'Communication Recommendation for a Council Decision authorising the opening of negotiations for a new partnership with the United Kingdom of Great Britain and Northern Ireland' COM (2020) 35 final 16. This recommendation is based on the revised political declaration on the future EU-UK relationship, cf. Political declaration of 12 November 2019 setting out the framework for the future relationship between the European Union and the United Kingdom [2019] OJ C384I/178.
} 
of financial stability, they made clear that "noting that both Parties will have equivalence frameworks in place that allow them to declare a third country's regulatory and supervisory regimes equivalent for relevant purposes, the Parties should start assessing equivalence with respect to each other under these frameworks as soon as possible after the United Kingdom's withdrawal from the Union." 117

Hence, the EU currently considers English law liabilities as other liabilities established under any third-country law. As a result, until the equivalence decisions are adopted, future MREL determinations and resolution procedures in the EU will not have issues regarding English law liabilities if the concerned credit institutions renegotiated contracts establishing those liabilities and inserting the "resolution-proof" clause, or if those (and the pre-BRRD) liabilities reached their maturity. All the existing English law liabilities which are pre-BRRD or not covered by the Article 55 requirement will maintain their problematic and risky status until a solution is found or until the EU and the UK introduce equivalence frameworks, or by the respective resolution authorities through specific case-by-case arrangement and/or recognition. Indeed, during the preparation of the TCA, while the UK engaged in equivalence decisions via the HM Treasury, ${ }^{118}$ the EU has not proceeded correspondingly. Concerning the methodology, the UK received the advice of the Bank of England (BoE), the Prudential Regulation Authority (PRA) and the Financial Conduct Authority (FCA), ${ }^{19}$ and acted in accordance with the Guidance of the HM Treasury ${ }^{120}$ focusing, among other aspects, on the extent to which the counterparty under assessment commits to the UK's regulation outcomes.

The equivalence decision framework of the EU is a complex procedure. Firstly, in 2019, by virtue of the EU financial services law ${ }^{121}$ which allows the Commission to adopt

\footnotetext{
117 Ibid.

${ }^{118}$ See HM Treasury, 'Policy paper: HM Treasury equivalence decisions for the EEA States' (November 2020) $<$ https://www.gov.uk/government/publications/hm-treasury-equivalence-decisions-for-the-eea-states-9november-2020/hm-treasury-equivalence-decisions-for-the-eea-states-9-november-2020> accessed 3 January 2020.

119 This procedure is based on a MoU between the HM Treasury, the BoE and the other two authorities. See Memorandum of understanding between HM Treasury, the Bank of England, the Prudential Regulation Authority and the Financial Conduct Authority: equivalence and exemptions [2019], which is, in turn, based on Regulation 6(3) of the Equivalence Determinations for Financial Services and Miscellaneous Provisions (Amendment etc) (EU Exit) Regulations 2019.

${ }^{120}$ HM Treasury, 'Guidance Document for the UK's Equivalence Framework for Financial Services' (November 2020)

$<$ https://assets.publishing.service.gov.uk/government/uploads/system/uploads/attachment_data/file/933506/Gui dance_Document_on_the_UK_s_Equivalence_Framework.pdf $>$ accessed 6 January 2020 .

${ }^{121}$ European Commission, 'EU banking and financial services law' $<$ https://ec.europa.eu/info/law/law-topic/eubanking-and-financial-services-law_en $>$ accessed 6 January 2020.
} 
equivalence decisions, it explained that it "may determine that the regulatory or supervisory regime of a third country is equivalent to the corresponding EU regime". ${ }^{122}$ The Commission, following the advice of the three European Supervisory Authorities (ESAs - in this case the EBA), has the duty to assess the equivalence of a third-country regime with respect to EU law. ${ }^{123}$ The correspondent country (i.e., the UK) will be assessed against the following elements and methods, which include a proportionate approach, ${ }^{124}$ a focus on outcomes and objectives rather than on the similarity of legislation or instruments, and safeguards for compliance with core EU policies areas. ${ }^{125}$ It is argued that, in line with the complexity and interconnectedness of the UK regime in banking and financial services, the Commission will likely take a considerable amount of time to complete such equivalence process.

Having said that, assuming that the Parties will be still eager to follow the path of equivalence in financial regulation, the future scenario can be summarised as follows. In the case that the UK government might decide to repeal EU regulations and directives, ${ }^{126}$ the powers which were mandated from the BRRD to the Bank of England, now part of domestic law, will cease, but similar regulations might be recognised by other EU resolution authorities, although the European Commission is supposed to act on behalf of the whole EU. The supporting argument ${ }^{127}$ relies on the fact that many of the proposals which derive from the Financial Stability Board (FSB) ${ }^{128}$ - in which the Bank of England and the HM Treasury are member institutions ${ }^{129}$ - were subsequently incorporated in the text of the BRRD. ${ }^{130}$ It is thus legitimate to assume that, following Brexit, the UK will continue to align with international and European standards, including those regarding the protection of contracts establishing

\footnotetext{
${ }^{122}$ Commission, 'Communication from the Commission to the European Parliament, the Council, the European Central Bank, the European Economic and Social Committee and the Committee of the Regions Equivalence in the area of Financial Services' COM (2019) 349 final 2.

${ }^{123}$ EU equivalence decisions can be consulted at European Commission 'Overview table Equivalence/adequacy decisions taken by the European Commission' (2020)

$<$ https://ec.europa.eu/info/files/overview-table-equivalence-decisions_en $>$ accessed 4 January 2020. Apart from the Commission, also the ESAs, the ECB and the SRB monitor the status of draft decisions.

${ }^{124}$ It can be more granular depending on the level of interconnectedness of the third country with the EU. It results that, concerning the UK, the assessment will be conducted with a higher attention to details.

${ }^{125}$ As competition or financial stability. The latter is in line with this study, as financial stability is one of the resolution objectives.

${ }^{126}$ In 2017, the UK Government led by the Prime Minister Theresa May presented the European Union (Withdrawal) Bill, known also as "The Great Repeal Bill", which had the aim of repealing the European Communities Act 1972, convert EU law into domestic law and modify those provisions considered no longer appropriate in the post-Brexit context.

${ }^{127}$ Apart from cost/benefit considerations related to a future disapplication of EU law in the UK.

${ }^{128}$ Referring particularly to the FBS's Key Attributes.

${ }^{129}$ See Financial Stability Board, 'FSB Members' (2020) <https://www.fsb.org/about/fsb-members/> accessed 9 August 2020.

${ }^{130}$ See the "bail-in tool" section.
} 
"bail-inable" financial instruments. This statement is supported by the UK's economic and finance ministry approach, which recognises that "some changes are required to reflect the UK's new position outside the EU", ${ }^{131}$ but specifies that, "the BRRD will remain a core element of [the UK resolution] regime, providing continuity and certainty as the UK leaves the EU, and conformity with the FSB Key Attributes." ${ }^{132}$ In addition, the recently approved text of the TCA, in its Article SERVIN.5.41 endeavours that the Parties will continue to align themselves and respect "internationally agreed standards in the financial services sector for regulation and supervision". ${ }^{133}$ Moreover, even if the TCA contains lesser provisions concerning financial services and equivalence in regulatory matters than what was desired by Boris Johnson, the Parties intend "to agree a memorandum of understanding on regulatory cooperation in financial services by March 2021".134 Such agreement could contain a framework for equivalence, including the recognition of English law liabilities as "bail-inable".

Progressing with the post-Brexit scenario, as the Parties reached an agreement in the immediate proximity of the expiry of the transition period, EU credit institutions could be in a position of constraint to include a "resolution-proof" clause on all contracts governed by English law. Otherwise, if EU credit institutions would decide to maintain current contracts lacking a "resolution-proof clause", the following adverse scenario might apply. In the event of a resolution procedure with a bail-in preferred resolution strategy, liabilities and instruments set with contracts that have relied upon the direct effect of the BRRD (hence, not including the "resolution-proof" clause) could be not immediately subject to the write down or conversion. In fact, the relevant resolution authority could decide to leave out those liabilities, therefore causing imbalances in the recovery of the losses and/or recapitalisation of the EU credit institution under resolution. However, the designated authority could decide to proceed by applying the bail-in tool also to those third-country law liabilities. In such a case, a duality of

\footnotetext{
${ }^{131}$ On the topic, see HM Treasury, 'Guidance: The Bank Recovery and Resolution and Miscellaneous Provisions (Amendment) (EU Exit) Regulations 2018: explanatory information' (October 2019) $<$ https://www.gov.uk/government/publications/draft-bank-recovery-and-resolution-and-miscellaneousprovisions-amendment-eu-exit-regulations-2018/the-bank-recovery-and-resolution-and-miscellaneousprovisions-amendment-eu-exit-regulations-2018-explanatory-information> accessed 12 August 2020. 132 Ibid.

${ }^{133}$ Article SERVIN.5.41, Trade and Cooperation Agreement between the European Union and the European Atomic Energy Community, of the One Part, and the United Kingdom of Great Britain and Northern Ireland, of the Other Part [2020] OJ L444/14.

${ }^{134}$ See 'Brexit offers Britain chance to do financial services differently - minister' [December 2020] Reuters $<$ https://www.reuters.com/article/britain-eu-idUSKBN2910BG> accessed 8 January 2020.
} 
situations would arise in relation to the behaviour of the court, in blocking the resolution decision or in disapplying the bail-in for certain liabilities.

\section{Conclusion}

The analysis developed in this paper shows the importance of the Article 55 requirement, even as it was conceived with the adoption of the BRRD back in 2014. Not predicting Brexit, the BRRD had already created a safeguard mechanism requiring credit institutions under its scope to include the recognition of the bail-in clause in all contracts involving the creation of liabilities which could be considered "bail-inable". Therefore, if all existing liabilities of EU credit institutions were "bail-inable," problems would have arisen solely concerning the liabilities established pre-BRRD with contracts prior to the implementation of the BRRD, which was expected by 31 December 2014. In addition, the introduction of the BRRD2, as explained, provides further implications due to amendments concerning Articles 45 and 55 BRRD. Accordingly, the UK did not adopt the BRRD2 as its transposition of the BRRD2 was set for the 28 December 2020, close to the end of the transition period.

In the introduction, this paper envisaged that the UK could repeal EU laws. However, considering that the latter have been already transposed into domestic law, the UK would rather modify selected provisions incompatible with its post-Brexit legal framework, than abrogate them. As a result, if the UK will decide to maintain alignment of its BIRC requirement to the BRRD, it is reasonable to expect for the resolution authorities of the "remaining" $27 \mathrm{EU}$ Member States to determine that "bail-inable" liabilities under English law will still be subject to write down and conversion. Determination could be handled directly via the envisaged equivalence procedure. Currently, all existing liabilities established with English law contracts must be compliant with the Article 55 requirement. Therefore, it is important to underline that the updates of the terms of new contracts provided by several credit institutions of the EU-27 are certainly helping to overcome this issue. Nevertheless, with reference to pre-BRRD existing contracts, the journey towards the protection of those liabilities still remains a challenge. 